\title{
Reconstruction of Spatial Planning Model of Marine and Small Islands Based Area as a Conflict Resolution Tool for Coastal and Marine Area Exploitation in Maluku
}

\author{
Dr Jantje Tjiptabudy S.H., M.Hum Dr. La Ode Angga, S. Ag, Sh, M. Hum \\ Faculty Of Law, Pattimura University
}

\begin{abstract}
The research, entitled "Formulation of Model of Spatial Planning Regulation on Marine and Small Islands as a Conflict Resolution of Coastal and Marine Area Utilization in Maluku Province", has a long-term goal to find the model formulation of Spatial Planning of Maluku Province based on maritime and small islands, so that Maluku Province is characterized by marine, coastal and small islands can organize the sea area well and optimally so that conflicts can be minimized.Approach method used in this research is juridical emperis or juridical sociology which is descriptive qualitative analysis. The study attempts to describe what happens in the coastal communities living around the conflicts that occur in these two research sites: Central Maluku (Malteng) and West Seram (SBB). Data collection techniques used in this study are: Interviews, questionnaires and literature study.This study found the answer that one of the causes of spatial use conflicts in coastal areas, sea and small islands in Maluku Province is because Maluku is one of the provinces in eastern Indonesia which has a strategic position between all western and central regions of Indonesia with Papua in the eastern part, and can link the southern regions including Australia and Timor Leste with northern regions such as North Maluku and Sulawesi. In order to resolve the conflict, there must be a reconstruction of the formulation model of the Rerda Spatial Plan of Maluku Region as one of the Provinces which is included in the archipelago Province in the archipelago by referring to various related laws and regulations.
\end{abstract}

Keywords: Model Arrangement, Spatial Planning of Marine and Small Islands, Conflict Resolution, Maluku Province.

DOI: $10.7176 / \mathrm{JLPG} / 87-02$

Publication date:July $31^{\text {st }} 2019$

\section{INTRODUCTION}

Indonesia is an archipelago consisting of 13,579 large and small islands connected to the sea. About $70 \%$ of Indonesia's territory consists of the sea. ${ }^{1}$ Of the $70 \%$ is in it entered Maluku Province. In Astronomy Maluku Province lies between 230 '-8 30 'South Latitude and 124-135 30' East Longitude, with area of 712.479,65 Km2 $(7.6 \%)$ is land area and $658.294,69 \mathrm{Km} 2(92,4 \%)$ is the vast ocean. ${ }^{2}$

As an archipelago provonsi, Maluku has 32 large and small islands. The islands of my past are Seram Island, Buru Island, Yamdena Island and Wetar Island. With the dominant territorial conditions of the waters, Maluku Province is very open to integrate with the surrounding provinces and countries. ${ }^{3}$

The development undertaken in the coastal areas of the sea and small islands often trigger the emergence of various conflicts. This is closely related to the spatial planning of coastal areas, marine and small islands, especially Maluku Province, there is no formulation of spatial planning model based on marine and small islands. The absence of formulation of spatial planning model of marine and small islands in Maluku Province resulted in various conflicts that arise, such as conflicts over the utilization of space and the sea area. Conflict occurred in Maluku Province in two kabuapten of Central Maluku Regency and West Seram District. In Central Maluku District conflict occurred between two villages namely Arara Village and Salemang Village District of North Seram with shrimp processing industry company. While West Seram District conflict occurred between Eti village and Osi village with local government in terms of utilization of hak ulayat (petuanan) coastal area. The question that should be related to the conflict above is, "Why is that conflict possible? Does this arise because one of them is the absence of arrangement of model formulation of Spatial Plan of Area based on marine and small islands in Maluku Province?

Regional Regulation No. 16 of 2013 concerning Spatial Planning of Maluku Province Year 2013-2033 (Regional Gazette of Maluku Province Number 16 of 2013), ${ }^{4}$ is a Regional Regulation made of course with the intent and purpose of so that all stakeholders (stakeholders) can be guaranteed needs and continuity of activities

\footnotetext{
${ }^{1}$ Wartini Soegeng, Pengukuran kapal Indonesia (Aspek Hukum) PT Refika Aditama, Bandung, 2000, p. 3.

${ }^{2} \mathrm{http}: / /$ www.boyyendratamin.com/2013/09/model-pengelolaan-sumber-daya-pesisir.html, diakses tanggal 21 Maret 20017. ${ }^{3}$ Ibid.

${ }^{4}$ La Ode Angga, Prinsip Kehati-Hatian Dalam Peraturan Daerah Rencana Tata Ruang Wilayah Provinsi Maluku Di Bidang Pengawasan Dan Evaluasi Berbasis Keberlanjutan Lingkungan Hidup, Malang: Disertasi Program Doktor Ilmu Hukum Fakultas Hukum Universitas Brawijaya Malang, 2015, p. 7.
} 
or business undertaken in the land area especially in the sea area. Given the sea, coastal and small islands in Maluku Province is getting more and more full use and utilization, it is appropriate if the region has a model formulation of spatial plan governance of marine areas and small islands to be a reference of interested parties. The fact that the existence of Regional Regulation No. 16 of 2013 on Spatial Planning of Maluku Province Year 2013-2033 has not been able to answer the wishes of all parties in the management of marine areas and small islands. ${ }^{1}$ The research that we will do is entitled, "Model of Spatial Plan Management of Marine and Small Islands as a Settlement Instrument of Conflict of Coastal Setup in Maluku Province", is aimed to find formulation of spatial model of marine areas and small islands so that can reduce the adverse impact of uncontrolled resource management optimizing its utilization. Given the enormous diversity of resource utilization in the region, ranging from the exploration of marine natural resources, the aspects of tourism, spiritual, fishing and other fishery products, the conservation of biososio-physical resources and education to the defense-security aspects. All sorts of interests that, if not clearly regulated, then one day will cause a friction of interests that will often lead to conflict. The high level of diversity in the use of coastal areas and small islands, as mentioned above also increases the complexity of marine spatial arrangements in the region. Have prepared a formulation of a comprehensive and integrated marine spatial planning model model that can accommodate the interests of all parties in the coastal areas of the sea and small islands.

One side of the pessimism or negative impact of the spatial plan arrangement in coastal areas and small islands, as mentioned above, is the emergence of a conflict of interest. However, the optimistic or fortunate side may include regulatory effectiveness, economic efficiency, and distribution distribution. Negative-cost-benefit or cost-benefit analysis is very commonly applied in the decision-making process in the present. The same regulatory modeling model can be applied to prepare master plan of spatial planning of Maluku Province in coastal area, sea and small islands. The spatial planning of coastal areas, seas and small islands in Maluku Province is a direction for the development of Maluku Province within a certain period of time that not only provides a clearer space and effort for stakeholders but also provides opportunities for the development of this region in the future come. ${ }^{2}$

The formulation of the spatial planning model, marine and small islands can also be an attractive selling point for investors interested in investing in coastal, marine and small islands in Maluku Province. In particular the model of coastal, marine and small island spatial arrangements is important to be studied in more depth, as coastal, marine and small island development is laden with overlapping and unclear priority concerns. On the other hand, the existence of the spatial layers of coastal areas and small islands will also greatly assist the development process of existing resources, especially the empowerment of human resources that are generally poor and underdeveloped.

With the above background, the research team aims to formulate the model of arrangement of marine and small island spatial plan in Maluku province as the answer of the problem problem faced today with the ultimate goal is to minimize the conflict that arises in the sea and islands small in Maluku Province, and as input for the Maluku Provincial Government in formulating policies on coastal, marine and small islands.

\section{PROBLEM FORMULATION}

a. What causes the conflict in the utilization of ulayat rights space (petuanan rights) in coastal areas, sea and small islands in Maluku Province?

b. How is the Formulation of Spatial Planning Model of the Province of Maluku Province Based on the Marine and Small Islands as an Instrument for Conflict Resolution of Coastal and Marine Area Exploitation in Maluku Province?

\section{RESEARCH METHODS}

\subsection{Types of research}

This research is conducted by using empirical juridical approach which is descriptive qualitative analysis. The research seeks to illustrate what is happening in coastal communities in Maluku Province (field). Quantitative data if possible later to be translated in percentage form presented in tabular form. The workings of the juridical method of empirical or sociological juridical in this research proposal is from the collection and discovery of data and information through literature study of assumptions or basic assumptions used in answering the problems in this study, then tested inductively-verifikatif on the latest facts within the community. Thus the truth in a study has been declared reliable without having to go through the process of rationalization.

${ }^{1}$ La Ode Angga, Nurjaya I Nyoman, Safa'ar Racmat, end Istislam, The Formulation of Precautionary Principle in the Local Regulation of Regional Spatial Order Plan Based on Life Environment Sustainability in Maluku Province, "Journal of Law, Policy and Globalization" Vol. 35 Tahun 2015, p. 3.

${ }^{2}$ Fauzi, 2005, Pengelolaan wilayah laut, Brawijaya Press, Malang, p. 5. 


\subsection{Research sites}

The location of this research is in two districts in Maluku Province namely Central Maluku Regency (Malteng) and West Seram District (SBB). In Kabupaten Maluku Tengah the research team took the location in two villages namely: Arara Village and Salemang Village located in District of North Seram. In West Seram District (SBB) the research team took location in two villages: Eti Village and Osi Village. Then each village was taken 5 people living in the vicinity of the coastal conflict of space utilization of marine areas, coastal, so the total number of 20 people as respondents. To complete the data, the research team also took several resource persons, namely:

a. The village head in the four (4) villages referred to in this study amounted to 4 village heads;

b. Non-governmental organizations (NGOs) engaged in the Environment in four villages totaling 4 people;

c. Stores Religion / Traditional Stores / Community Stores / and Youth Stores that live around the conflicts of coastal and marine space utilization, in four (4) Villages that are the location of this study, totaling 4 people. Sehinngga all amounted to 32 People.

\subsection{Data source}

Sources of data used in this study, is secondary data (secondary data) and primary data (primary data). Secondary data is data obtained by the research team from literature research and documents, which is the result of research and processing of others, which are available in the form of books or documents that are usually provided in libraries, or private property. While the primary data is the data obtained directly from the community. In legal research, secondary data includes primary legal materials, secondary law materials, and tertiary legal materials. Secondary data used in this study, which consists of:

\subsection{Data collection technique}

Data collection techniques in this study will be collected based on the problems formulated and classified according to the source for then studied in a comprehensive and comprehensive. The data collection phase will first be done through literature study which consists of inventory that is collecting data in accordance with the object of this research. The technique of collecting known data is literature study; observation, interview, and questionnaire. In accordance with the data source as described above, then in this study data collection is done by:

3.4.1. Interview

Against field data (seunder) collected by non-directive interview technique or free flowing interview that is by conducting direct communication to informant, by using interview guide (interview guide) to find answer Problem formulated in research this. This technique is used as an instrument to be able to obtain data by holding questions directly to the informants by using interview guides that have been prepared previously by the research team.

3.4.2. Questionnaire

This technique is used as an instrument to obtain data by holding tabya answers with respondents by using a list of questions that have been prepared before by the research team.

3.4.3. Library Studies

Literature study is done by studying the books in this case referred to the existing laws and regulations related to this research, research results daei previous researchers, all of which have something to do with this research material.

3.4.4. Implementation Procedures

The research is descriptive, want to give an idea What causes the conflict of space utilization in coastal area, sea and small islands in Maluku Province? Then How is the Formulation of Spatial Planning Model for the Province of Maluku Province Based on the Marine and Small Islands as an Instrument of Conflict Resolution of Coastal and Marine Area Exploitation in Maluku Province?

To answer the problem as mentioned above, then that will be done as follows:

a. Primary data obtained from respondents and resource persons who have been selected or determined, questionnaire questionnaire given to the respondents

b. while wawacara submitted to the resource persons using wawacara guidelines that have been prepared by the research team before pelkasanaan research began.

c. Secondary data obtained from the results of research through literature study, the results of previous research, legislation, other documents that all have kaitanya with this research material.

\subsection{Data analysis technique}

All data have been collected both primary and secondary data, studied and analyzed in depth so as to obtain a full and in-depth conclusion. Technique used to analyze data, both primary data and secondary data that has been 
collected from document studies and library materials identified and then grouped, reviewed and described according to the hierarchy.

For complete this research method see the flow of research with a diagram of the research flow that describes what will be done and that has been implemented in 1 or 2 years in the form of fishbone diagram, as follows:

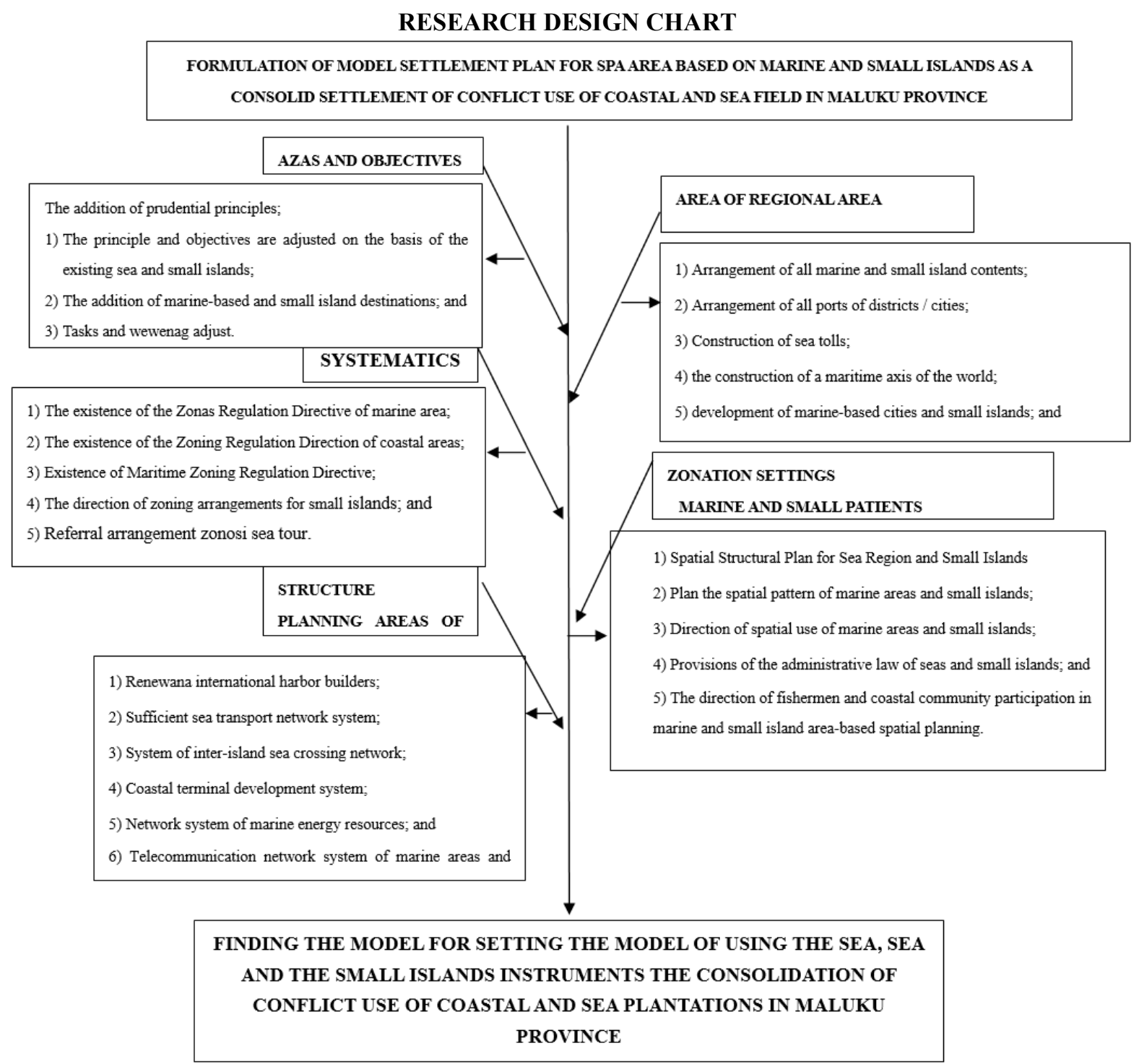

\section{RESULTS AND DISCUSSION}

\subsection{Understanding Conflict}

Conflict is a word derived from the Latin "can" together and "fligera", or the beginning of a movement. Conflict can be interpreted as a weapon attack in combat, or the beginning of a movement. An environmental conflict can be defined as a conflict of interests, values, actions or objectives among individuals, groups or communities, or governmental bodies of the State concerning environmental issues. Environmental conflicts are not solely on the issue of pollution and / or environmental destruction, but may involve a conflict between interests in natural resource management (forests, water, land, mined and marine resources), or arising from governance problems the value of social and cultural comfort due to wrong decision-making in development.

It should be noted that conflicts can be categorized into two, namely: (1) emerging (Manifest) and (2) not appearing (Unmanifest). In conditions of society with cultural culture that emphasizes peace with the harmony of social relations such as Indonesia as if atua there is no conflict or no conflict. However, it is possible that many conflicts, only the conflict does not appear so that it is not visible and well resolved. In many cases, conflicts are also invisible because of an authoritarian and arrogant political social system, as happened in the New Order. In the context of environmental conflicts it is necessary to examine the possibility of many conflicts that do not 
arise but in fact involve a very significant environmental problem.

\subsection{Local regulation}

As a Public Policy Instrument, in order for a public policy to have valid power (power), it needs to be formulated in a certain legal form, namely legislation. At the regional level, policies relating to the affairs of local governance should be set forth in local legislation, so that the policy has a force of force and force for those who are unwilling to comply. Understanding of what constitutes the affairs of regional government administration is part of the material of constitutional law or more specifically the law of regional governance and it is noteworthy that the holder of power over public policy in the region based on Law No. 32 of 2004 on Regional Government is called the Regional Governance Law, namely the Governor or the Regional Head by implementing the obligations mandated by legislation, the Regional Head has the obligation to obey and enforce all laws and regulations; (Article 27 letter e of Law No. 32 Year 2004) as well as the obligation to issue regional policies and one of them is the governor's regulation and the regional regulation should be subject to the principles of drafting legislation as part of regional legislation.

The question of what is meant by the implementation of Regional Government, Law No. 32 Year 2004 states:

"That the Regional Government is the implementation of government affairs by the regional government and the Regional People's Legislative Assembly according to the principle of autonomy and duty of assistance with the principle of autonomy as wide as possible in the system and principle of the Unitary State of the Republic of Indonesia as referred to in the Constitution NKR (Article 1 point 2) is the Governor, Regent, or Mayor, and regional apparatus as an element of local government administration. And the Regional People's Legislative Assembly, hereinafter referred to as DPRD, is a representative institution of the regional people as an element of local government administration. (Article 1 Sub-Article 4 of Law No. 32 Year 2004)".

In Chapter IV Implementation of Government The First Section of Government Administration in Article 19 paragraph (2) states:

"The organizer of the regional government is the regional government and the Regional People's Legislative Assembly and should also pay attention to the principles of good governance and or the principle of governmental administration Article 20 paragraph (1) The implementation of government shall be based on the principle of the State Administration which consists of, law; principle of openness ".

Article 20 Paragraph (3) letter 0 Act no. 32 Year 2004:

"In carrying out local government, local government uses the principle of autonomy and duty of assistance and in carrying out autonomy, the region has an obligation under Article 22 letter 0 which states: other obligations set forth in legislation.

Duties and Powers and Obligations of Regional Head and Deputy Regional Head Article 25 The regional head shall have duties and authorities in letter g: perform other duties and authorities in accordance with laws and regulations and shall also be obliged to observe Article 27 paragraph (1):

"In executing the duties and authorities as referred to in Article 25 and Article 26, to

\subsection{Analysis of the Cause of Conflict of Land Use of Ulayat Right In Coastal Area, Sea And Small Islands In Maluku Province.}

One of the causes of spatial use conflicts in coastal areas, sea and small islands in Maluku Province is because it is one of the provinces in eastern Indonesia with a strategic position between all western and central regions of Indonesia with Papua in the east. Likewise it can connect southern regions including Australia and Timor Leste with northern regions such as North Maluku and Sulawesi. This position led to the province of Maluku as a cross point that has an important role as a transit area. The condition of this archipelago gives significance to the prospect of regional economic development that is not only based on the land area, but most will lead to coastal, marine and small islands.

Marine, coastal and small island resources in Maluku Province is one of the basic capital of development for this Province on the special and development of the Indonesian nation in general, in addition to the terrestrial natural resources that must have formulation of spatial regulatory arrangement model of marine, coastal and small islands. Currently, terrestrial natural resources such as oil and gas and certain minerals and plantation and agricultural products, are diminishing due to long-lasting exploitation and environmental quality degradation. Seeing the limitations of the land's natural resources, it is time to look at and utilize the potential of marine resources. In the sea contained very large food sources such as: fish, shrimp, seaweed, and others. Other marine resources are offshore mining materials that play an important role in supplying energy, as well as many other potential marine biological and non-biological resources so that the role of coastal and marine resources is increasingly important to trigger economic growth and community needs. In coastal areas and small islands there are many important issues in it, including entrepreneurs or investors, in order to find the value of capital, which 
sometimes they do the development of shrimp processing industry without paying attention to the interests of local communities or indigenous peoples, in two locations in this study.

According to the theory of state welfare law, one of the duties of the state or government and local government is as the organizer of the public interest. This general interest becomes very widespread, the possibility of violating the interests of the people by the state or regional apparatus also becomes very widespread. In carrying out the task, the state administration requires independence, namely independence to be able to act on its own initiative, especially in resolving the critical issues that arise where the regulation does not yet exist. Because of the wide function of the government and local government in the context of the modern legal state or state welfare law, it is of course the broader role of administrative law in it, as well as in the affairs of the formation of Provincial RTRW of Maluku Province which aims to welfare maluku community in the field of territorial arrangement especially coastal and small islands.

\subsection{Reconstruction of Spatial Model Formulation of Spatial Planning of Maluku Province Based on Ocean and Small Islands as an Instrument of Conflict Resolution of Coastal and Marine Area Exploitation in Maluku Province}

To reconstruct the formulation of spatial planning model of maluku province based on marine and small islands as an instrument to solve the conflict of coastal and marine area utilization in Maluku Province as follows:

4.4.1. "Systematic"

In Perda no. 16 of 2013 on the RTRW of Maluku Province, the regulation on "Systematic" is regulated in Article 3, namely:

The Spatial Plan as referred to in Article 2 shall include:

a. The objectives and policies of spatial planning, for the improvement of public welfare and defense of security embodied through the implementation strategy of spatial use of space for the achievement of the use of quality space;

b. Provincial Spatial Structure Plan which includes the urban system in the territory related to rural areas within its service area;

c. Provincial Spatial Plan Pattern covering protected areas and cultivation areas that have a strategic value of the Province;

d. Provision of the Provincial Strategic Area;

e. Referral of spatial use of Provincial Area;

f. Directive guidance on controlling the utilization of provincial spatial space; and

g. The Role of Society.

In Article 2 which regulates the "systematic" authors do the formulation with the addition of: g. Guidance for managing spatial area of sea, coastal and small islands, so the formula is as follows: Spatial Plan as referred to in Article 2 covers:

a. The objectives and policies of spatial planning, for the improvement of public welfare and defense of security embodied through the implementation strategy of spatial use of space for the achievement of the use of quality space;

b. Provincial Spatial Structure Plan which includes the urban system in the territory related to rural areas within its service area;

c. Provincial Spatial Plan Pattern covering protected areas and cultivation areas that have a strategic value of the Province;

d. Provision of the Provincial Strategic Area;

e. Referral of spatial use of Provincial Area;

f. Directive guidance on controlling the utilization of provincial spatial space; and

g. Directive guidance of managing the space of marine areas, coastal and small islands, and

h. The Role of Society.

\subsection{2. "Azas" and "goals"}

"Principles" and "objectives" are stipulated in Article 4 as follows: Principles, Objectives, Policies and Strategy of Spatial Planning of Provinces.

First Section Principles

Article 4 states: The Spatial Plan as referred to in Article 2 shall be based on:

a. Integration;

b. Harmony, harmony and balance;

c. Sustainability;

d. Usability and effectiveness;

e. Openness;

f. Togetherness and partnership;

g. Protection of the public interest; 
h. Legal certainty and justice; and

i. Accountability.

In Part Two which governs the Objectives in Article 5, the authors undertake the formulation of additions to the words coast and islands, so that Article 5 reads as follows:

The Provincial Spatial Plan is aimed at realizing the Maluku Province as a safe, convenient, productive and sustainable Islands Province based on marine, coastal and small islands, fisheries, tourism, mining and plantations for the improvement of the region's economy through the development of a linkage system national interest based disaster mitigation.

4.4.3. Marine Area Structure Plan

In the Marine Area Structure Plan, the authors add the formulation of an "international port" previously mentioned in Article 24 paragraph (1) stating: The plan of marine transportation infrastructure, encompassing the development of major ports, gathering ports and feeder ports. Article 24 paragraph (1) after the authors reconstructed: Sea transport infrastructure plan, covering international port, development of main port, gathering port and feeder port.

Article 24

(1) Sea transport infrastructure plan, covering "international port development", main port, gathering port and feeder port.

(2) Main Port as meant in sub-article (1) covers Yos Soedarso Ambon Port.

(3) Collecting Port as meant in sub-article (1) consists of:

(a) port Tulehu Kec. Salahutu Regency of Central Maluku;

(b) port of Amahai in Central Maluku District

(c) Namlea port in Buru District;

(d) Tual port in Tual City;

(e) Dobo port in Aru District; and

(f) port of Saumlaki in West Southeast Maluku District.

4.4.4. Marine and Pulau-Pualau Kecil

Indications of Zoning Regulation Directives In the indication of the zoning rules directive the author performs reconstruction of the formula by adding "international port", so that becomes:

For Sea Transportation Network System

Article 69

Indications of zoning regulations for marine transportation systems as referred to in Article 63 letter c consist of:

a. indication of the direction of zoning regulations for "international port", interprovincial;

b. Indikasi directives of zoning regulations for "international ports", provincial ports; and

c. indication of zoning regulations for the shipping path. Article 70

(1) Indications of zoning regulations for interna- tional ports consist of:

(a) developing facilities and facilities of international port management capable of performing and adopting modern management pattern so as to serve the loading and unloading of goods with high intensity;

(b) developing immigration, customs and quarantine services that meet international standards;

(c) developing port security system based on high technology and advanced;

(d) developing a container jetty with a length of 350 (three hundred and fifty) meters or more, 4 (four) cranes, and a container container field of 15 (fifteen) hectares or more with international standards;

(e) develop loading and unloading facilities so as to be able to serve the freight of international and inter- provincial container shipment with the capacity of 3,000,000 (three million) TEU's per year or more or other equivalent transportation.

(2) Indications of zoning regulations for interprovincial ports consist of:

(a) prepares a port space allocation plan that can meet space requirements for the development of port activities and infrastructure;

(b) developing interprovincial port facilities and management facilities capable of adopting modern management patterns so as to serve the loading and unloading of goods with high intensity;

(c) developing immigration, customs and quarantine services that meet inter-provincial standards;

(d) developing high-tech port-based security system;

(e) developing a container jetty with a length of 350 (three hundred and fifty) meters or more, 4 (four) cranes, and a container container field of 15 (fifteen) hectares or more;

(f) developing loading and unloading facilities so as to be able to serve the transport of container and province interprovincts over 3 million (three million) TEUs per year or more or other equivalent transportation; 
(g) integrating interprovincial ports with land transportation systems connecting interprovincial ports with the nearest PKN and regional production centers;

(h) preparation of a regional environmental study that considers protected area conservation and environmental carrying capacity in general to complement the port development plan;

(i) ensure the availability of clean water, electricity, telecommunication networks, and wastewater treatment plants in the port area.

(3) Indications of zoning regulations for the Provincial port are as follows:

(a) prepares a port space allocation plan that can meet space requirements for the development of port activities and infrastructure;

(b) developing a port capable of functioning as a provincial sea transport node connecting a feeder port with a higher hierarchy port;

(c) developing a provincial standard security system;

(d) integrate the provincial port with a land transportation system that connects the port with the PKN or the nearest PKW and other regional production centers

(e) developing ports capable of serving container transport;

(f) developing multifunctional docks of 150 (one hundred and fifty) meters or more, Cranes with capacity of 50 (fifty) tons or more;

(g) prepare a regional environmental study that considers protected area conservation and environmental carrying capacity in general to complement the port development plan;

(h) develop a passenger terminal to serve provincial shipping and / or crossings; and

(i) ensure the availability of clean water, electricity, telecommunication networks, and wastewater treatment plants in the port area.

(4) Indications of zoning regulations for the following shipping channels:

(a) developing an interprovincial standardized safety and security system along with its facilities along the provincial and provincial shipping lanes and the provincial standard shipping security system along the provincial shipping lanes;

(b) arranging the allocation of space for cultivation activities on the coast and small islands around the cruise line;

(c) regulating the allocation of seabed space for natural resource management and placement of infrastructure along the shipping route;

(d) integrating interprovince shipping networks with provincial shipping networks and ports served;

(e) integrating interprovince shipping networks with provincial shipping networks and ports served; and

(f) develop a ship impact accident control system.

\section{CONCLUSIONS}

The conclusions that the authors point out in this paper are:

a. One of the causes of spatial use conflicts in coastal areas, sea and small islands in Maluku Province is because Maluku is one of the provinces in eastern Indonesia that has a strategic position between all western and central regions of Indonesia with Papua in the east, and can connect southern regions including Australia and Timor Leste with northern regions such as North Maluku and Sulawesi.

b. In order to resolve the conflict, there must be a reconstruction of the formulation model of the Rerda Spatial Plan of Maluku Region as one of the Provinces which is included in the archipelago Province in the archipelago by referring to various related laws and regulations.

\section{REFERENCES}

1. Books Papers, Journals, Dictionaries.

Abbas Syahrizal, MEDIASI dalam Hukum Syari'at, Hukum Adat, dan Hukum Nasional, Jakarta: Prenada Media Group, 2011.

Angga La Ode, Nurjaya I Nyoman, Safa'ar Racmat, end Istislam, The Formulation of Precautionary Principle in the Local Regulation of Regional Spatial Order Plan Based on Life Environment Sustainability in Maluku Province, "Journal of Law, Policy and Globalization" Vol. 35 Tahun 2015.

Angga La Ode, Prinsip Kehati-Hatian Dalam Peraturan Daerah Rencana Tata Ruang Wilayah Provinsi Maluku Di Bidang Pengawasan Dan Evaluasi Berbasis Keberlanjutan Lingkungan Hidup, Malang: Disertasi Program Doktor Ilmu Hukum Fakultas Hukum Universitas Brawijaya Malang, 2015.

Deutsch Morton, The resolution of conflict, 1973, New Heaven: Yale University, Press. Fauzi, Pengelolaan wilayah laut, Brawijaya Press, Malang, 2005.

Jamil M. Mukhsin, Mengelola konflik membangun Damai; Teori, Strategi, dan Implementasi Resolusi Konflik, Semarang: Walisongo Mediation Center (WMC). 
Liliweri Alo, Prasangka dan konflik; komunikasi lintas budaya masyarakat multicultural, 2007.

Soerjono Soekanto, Pengantar Penelitian Hukum, Universitas Indonesia, UI-Press, Jakarta, 2005.

Soegeng, Wartini, Pengukuran kapal Indonesia (Aspek Hukum), PT Refika Aditama, Bandung, 2000.

Supryono, Harry, Manajemen Konflik dan penyelesaian masalah lingkungan, Kursus Amdal Tipe A Kerja Sama Pslh UGM dengan kemetrian lingkungan hidup, Yogyakarta, 3003.

Sumardjono, Maria SW, Pendoman Pembuatan Usulan Penelitian Sebuah Panduan Dasar, Penerbit Gramedia Pustaka Utama. Jakarta, 2001.

Tafsir M.A M., Resolusi Konflik, Semarang, CV. Karya Abadi Jaya, 2015.

Taufiq Imam, Peace Building dalam al-quran; Kajian tentang Pemikiran Sayyid Qutb dalam Tafsir Fi Dilal Al-qur'an (Laporan Penelitian Individu).

\section{Law}

Undang-Undang Dasar Negara Republik Indonesia Tahun 1945.

Undang-Undang No. 5 Tahun 1960 tentang Peraturan Dasar Pokok-Pokok Agraria Lembaran Negara Republik Indonesia Tahun 1960 No. 104, Tambahan Lembaran Negara Republik Indonesia No. 2034.

Undang-Undang No. 32 Tahun 2009 tentang Perlindungan dan Pengelolaan Lingkungan Hidup, Lembaran Negara Republik Indonesia Tahun 2009 No. 140 Tambahan Lembaran Negara Republik Indonesia No. 5059 .

Undang-Undang No. 26 Tahun 2007 tentang Tata Ruang Lembaran Negara Republik Indonesia Tahun 2007 No. 68 Tambahan Lembaran Negara Republik Indonesia No. 4725.

Undang-Undang No. 27 Tahun 2007 Tentang Pengelolaan Wilayah Pesisir Dan Pulau-Pulau Kecil, Lembaran Negara Republik Indonesia Tahun 2007 No. 84, Tambahan Lembaran Negara Republik Indonesia No. 4739, Joncjo Undang-Undang No. 1 Tahun 2014 Tentang Perubahan Atas Undang-Undang No. 27 Tahun 2007 TentangPengelolaan Wilayah Pesisir Dan Pulau-Pulau Kecil, Lembaran Negara Republik Indonesia Tahun 2014 No. 2, TambahanLembaran Negara Republik Indonesia No. 5490.

Peraturan Daerah Provinsi Maluku No. 16 Tahun 2013 tentang RTRW Provinsi Maluku Tahun 1013-2033, Lembaran Daerah Provinsi Maluku No. 16 Tahun 2013.

Undang-undang Nomor 32 Tahun 2004 tentang Pemerintahan Daerah Lembaran Negara No. 125 dan Tambahan Lembaran Negara No. 447.

\section{Website}

http://webcache.googleusercontent.com/search?q=cache:http://www.australiaawardsindonesia.org/files/alumni/P DAslides/PDA.Ambon-Yvonne.pdf, diakses tanggal 23 Maret 2017.

http:/www.boyyendratamin.com/2013/09/model-pengelolaan-sumber-daya-pesisir.html, diakses tanggal 21 Maret 20017.

http://selamatkanlingkungan99.blogspot.co.id/2014/07/konflik-lingkungan-hidup.html, diakses tanggal 31 Maret 2017. 